Check for updates

Cite this: RSC Adv., 2017, 7, 34664

\title{
DBP and $\mathrm{C}_{70}$ based inverted tandem solar cells using a simple interconnecting layer $\dagger$
}

\author{
Zhongqiang Wang, (D) *a Takeshi Sano, ${ }^{\text {t }}$ Taojun Zhuang, ${ }^{\mathrm{b}}$ Hisahiro Sasabe ${ }^{\mathrm{b}}$ \\ and Junji Kido*b
}

Inverted tandem structure cells with a simple interconnecting layer based on tetraphenyldibenzoperiflanthene (DBP) and fullerene-70 $\left(\mathrm{C}_{70}\right)$ were studied in this work. Two subcells using identical donor and acceptor materials were connected by a molybdenum trioxide and calcium $\left(\mathrm{MoO}_{3} / \mathrm{Ca}\right)$ interlayer in series. An outstanding fill factor (over $80 \%$ ) under concentrated power intensity has been observed. Meanwhile, the open circuit voltage is approximately equal to the sum of the two subcells, revealing the excellent properties of $\mathrm{MoO}_{3} / \mathrm{Ca}$ as a recombination layer for tandem structured cells. On the other hand, the main loss mechanisms of charge carriers are analyzed; Schokley-Read-Hall and bimolecular recombination dominate the charge recombination in the tandem structured cells under low and high power intensities, respectively.

Received 21st April 2017

Accepted 6th July 2017

DOI: $10.1039 / \mathrm{c} 7 \mathrm{ra0} 4501 \mathrm{~h}$

rsc.li/rsc-advances

the tandem structure cells with identical materials show

\section{Introduction}

As a potential technology for clear and renewable energy, the performance of organic photovoltaic cells (OPVs) has been dramatically enhanced, which makes this technology a competitive alternative to inorganic photovoltaic cells. ${ }^{1-4}$ OPVs using conjugated polymer and small-molecule electron donor materials blended with fullerene and non-fullerene materials as electron acceptor materials have achieved over $12 \%$ power conversion efficiency (PCE) in single bulk heterojunction (BHJ) structured devices. ${ }^{2-5}$ In recent years, much attention has been paid to the field of small-molecule based OPVs, and to date the PCE have reached $10 \%$ and $12 \%$ in single- and multi-junction cells, respectively. ${ }^{4,6}$ However, the intrinsic properties (low charge mobility, short exciton diffusion length, narrow absorption bandwidth) of organic semiconductors limit further improvement in OPVs. For more effectively improving the performance, a simple and useful method is to design tandem structure cells via stacking multiple photoactive layers with complementary absorption spectra. ${ }^{5,7,8}$ Meanwhile, subcells using identical materials have also been tried in polymer based tandem structure cells. Comparison with single junction cells,

${ }^{a}$ Key Laboratory of Interface Science and Engineering in Advanced Materials (Ministry of Education), Research Center of Advanced Materials Science and Technology, Taiyuan University of Technology, Taiyuan, 030024, China. E-mail: wangzhongqiang@tyut.edu.cn

${ }^{b}$ Department of Organic Device Engineering, Graduate School of Science and Engineering, Research Center for Organic Electronics (ROEL), Yamagata University, 4-3-16 Jonan, Yonezawa, Yamagata 992-8510, Japan. E-mail: kid@yz.yamagata-u. ac.jp

$\dagger$ Electronic supplementary information (ESI) available. See DOI: 10.1039/c7ra04501h enhanced light harvesting and decreased charge carriers recombination. Usually, the tandem structure has positive contribution to the photovoltaic performance. ${ }^{9-11}$

The typical tandem structure cells are connected with subcells in series through interconnecting layers. An effective and simple interconnecting layer not only affects the performance of cells but also influences the device procedure. Due to the multiple effects, the interconnecting layer plays a key role in tandem structure cells. For a good interconnecting layer, it should satisfy some requirements, including high conductivity, excellent transparency and easy processing. ${ }^{12}$ Hence, n-type metal oxides with high conductivity are widely selected as connecting layers in tandem structure cells. ${ }^{13,14}$ In this paper, molybdenum trioxide $\left(\mathrm{MoO}_{3}\right)$ and calcium (Ca) were applied as hole and electron collecting layers in each subcells. Meanwhile, $\mathrm{MoO}_{3} / \mathrm{Ca}$ was used as the recombination layer in tandem structure cells. More importantly, our results proved that $\mathrm{MoO}_{3} /$ $\mathrm{Ca}$ is an efficient charge carrier recombination center for tandem structure cells. On the other hand, photovoltaic performance and inside recombination mechanism were studied in this tandem structure cells.

\section{Experimental}

Tetraphenyldibenzoperiflanthene (DBP) and fullerene-70 $\left(\mathrm{C}_{70}\right)$ were purified three times by thermal sublimation. Pre-patterned indium-tin-oxide (ITO) coated substrates were cleaned by detergent, deionized water, acetone and isopropanol in sonication, and treated in UV-ozone for 30 min before loading into vacuum chamber. The organic layers and metal electrodes were thermally deposited in sequence on pre-cleaned substrates in 
a vacuum chamber with base pressure of $1 \times 10^{-6} \mathrm{~Pa}$. The thicknesses and deposition rates were monitored by quartz crystal sensors. The deposited rates of organic materials were controlled at 0.2-0.3 $\mathrm{A} \mathrm{s}^{-1}$. Aluminum (Al) deposited rate was $\sim 5 \AA \mathrm{s}^{-1}$. The active area of individual OPVs is $\sim 3 \times 3 \mathrm{~mm}^{2}$, defined by the overlap of the ITO and Al electrodes. The madeup cells were transferred back to a nitrogen protected glovebox for encapsulation, and then brought to ambient condition for measurement of both efficiency (PCE and EQE) and current density-voltage $(J-V)$ characteristics using a CEP-2000 integrated system by Bunkoukeiki Co. Light state $J-V$ characteristics were measured under simulated $100 \mathrm{~mW} \mathrm{~cm}^{-2}$ AM1.5G irradiation. Integrating current density from EQE curve under AM1.5G solar spectrum showed $<5 \%$ discrepancy with $J_{\text {sc }}$ extracted from $J-V$ curves.

\section{Results and discussion}

Fig. 1(a) shows the tandem device configuration and Fig. 1(b) shows the chemical structure of DBP and $\mathrm{C}_{70}$. As discussed in ref. 15 , much interaction between $\mathrm{DBP}$ and $\mathrm{C}_{70}$ on a molecular level were allowed due to the planar backbone of DBP molecule, which contributes to the strong charge transfer states in DBP and $\mathrm{C}_{70}$ heterojunction system.

We adopted the inverted tandem structure to achieve stable and reproducible cells. Moreover, we employed DBP and $\mathrm{C}_{70}$

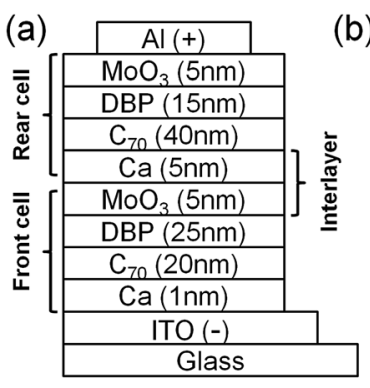

(b)

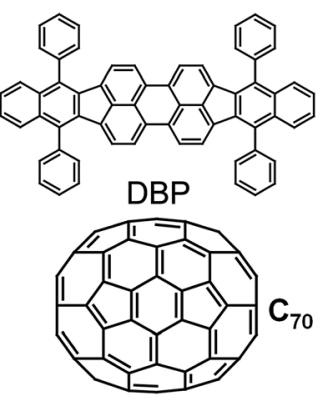

Fig. 1 (a) Configuration of inverted tandem solar cells. The shown thicknesses were the optimal values for DBP and $\mathrm{C}_{70}$ based tandem structure cell. (b) Chemical structures of DBP and $C_{70}$. system in tandem structure cells for efficient light harvesting. As shown in Fig. 2(a), the absorption of the two $\mathrm{C}_{70} / \mathrm{DBP}$ subcells has been significantly enhanced compared with the single junctions (front cell and rear cell).

In designing high performance interconnecting layer in tandem structure cells, good transmittance is the first priority. Therefore, the transmittance of $\mathrm{MoO}_{3} / \mathrm{Ca}$ interlayer was studied. As shown in Fig. 2(b), the interconnecting layer of $\mathrm{MoO}_{3} / \mathrm{Ca}$ displays high transmittance in the range from $300 \mathrm{~nm}$ to $800 \mathrm{~nm}$. The value of transmittance is over $99 \%$ when the wavelength is beyond $500 \mathrm{~nm}$. The high transmittance benefits the light absorption in tandem structure cells.

Excellent photovoltaic property of DBP has been confirmed in our past work. Relevant papers were published in ref. 15 and 16. The complementary absorption spectra of $\mathrm{DBP}$ and $\mathrm{C}_{70}$ show strong absorption from near UV range to about $650 \mathrm{~nm}$. High extinction coefficient and anisotropy property have been observed in vacuum deposited DBP films. The highest occupied molecular orbital (HOMO) and lowest unoccupied molecular orbital (LUMO) energy levels of DBP are $-5.5 \mathrm{eV}$ and $-3.5 \mathrm{eV}$, respectively. As a result, high open circuit voltage $\left(V_{\mathrm{oc}}\right)$ of $0.9 \mathrm{~V}$ was obtained in $\mathrm{DBP} / \mathrm{C}_{70}$ planar junction cells, consistenting with the difference between HOMO energy level of DBP and LUMO energy level of $\mathrm{C}_{70} \cdot{ }^{17}$ The energy level diagram was shown in ESI Fig. SI $1 . \dagger$

As a recombination layer, the contact between $\mathrm{MoO}_{3}$ and $\mathrm{Ca}$ dominates the performance in tandem structure cells. Therefore, experiment was designed to study the interfacial contact between $\mathrm{MoO}_{3}$ and Ca. As shown in ESI Fig. SI 2 and Table SI 1, $\dagger$ the optimal Ca thickness was set to $1 \mathrm{~nm}$. Two device structures were designed: device (I) ITO/Ca $(1 \mathrm{~nm}) / \mathrm{C}_{70}(40 \mathrm{~nm}) / \mathrm{DBP}(20$ $\mathrm{nm}) / \mathrm{MoO}_{3}(5 \mathrm{~nm}) / \mathrm{Al}$, device (II) ITO $/ \mathrm{MoO}_{3}(5 \mathrm{~nm}) / \mathrm{Ca}(1 \mathrm{~nm}) / \mathrm{C}_{70}$ $(40 \mathrm{~nm}) / \mathrm{DBP}(20 \mathrm{~nm}) / \mathrm{MoO}_{3}(5 \mathrm{~nm}) / \mathrm{Al}$. The photovoltaic performances of device (I) and device (II) were summarized in Table 1. As listed in the table, similar $J_{\mathrm{sc}}, V_{\mathrm{oc}}$, FF and PCE were achieved from device (I) and (II). Meanwhile, the series resistance $\left(R_{\mathrm{s}}\right)$ and shunt resistance $\left(R_{\mathrm{sh}}\right)$ of device (I) and (II) were extracted from $J-V$ curves, which were also similar. Comparable photovoltaic performance and resistances mean good electrical contact between $\mathrm{MoO}_{3}$ and $\mathrm{Ca}$. On the other hand, the optical transparency of $\mathrm{MoO}_{3}$ film has been confirmed in OPVs. ${ }^{\mathbf{1 8 , 1 9}}$
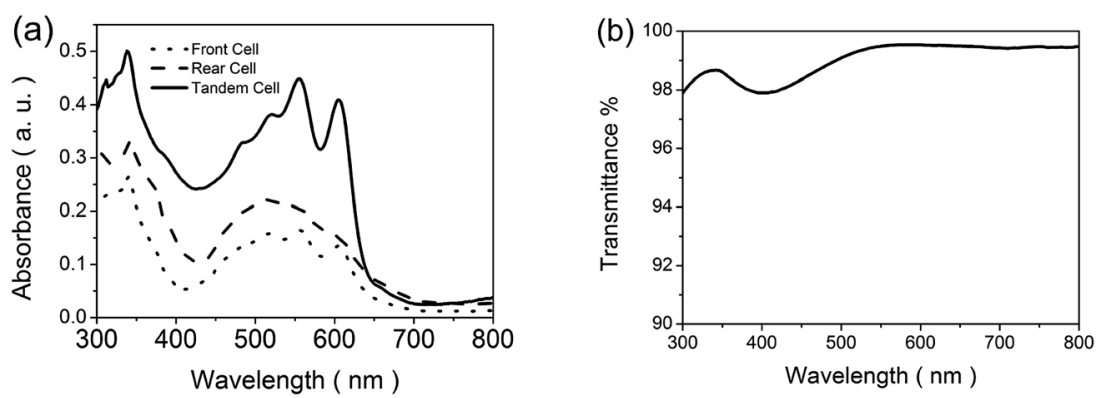

Fig. 2 (a) Absorbance of tandem structure cell and single junction cells (front cell and rear cell). The tandem structure is ITO/Ca (1 $\mathrm{nm}) / \mathrm{C}_{70}(20$ $\mathrm{nm}) / \mathrm{DBP}(25 \mathrm{~nm}) / \mathrm{MoO}_{3}(5 \mathrm{~nm}) / \mathrm{Ca}(5 \mathrm{~nm}) / \mathrm{C}_{70}(40 \mathrm{~nm}) / \mathrm{DBP}(15 \mathrm{~nm}) / \mathrm{MoO}_{3}(5 \mathrm{~nm})$. The front cell structure is ITO/Ca $(1 \mathrm{~nm}) / \mathrm{C}_{70}(20 \mathrm{~nm}) / \mathrm{DBP}(25$ $\mathrm{nm}) / \mathrm{MoO}_{3}(5 \mathrm{~nm})$. The rear cell structure is ITO/Ca $(5 \mathrm{~nm}) / \mathrm{C}_{70}(40 \mathrm{~nm}) / \mathrm{DBP}(15 \mathrm{~nm}) / \mathrm{MoO}_{3}(5 \mathrm{~nm})$. (b) Transmittance of interlayer of MoO $3(5 \mathrm{~nm}) /$ $\mathrm{Ca}(5 \mathrm{~nm})$. 
Table 1 Photovoltaic performance, series resistance $\left(R_{\mathrm{s}}\right)$ and shunt resistance $\left(R_{\mathrm{sh}}\right)$ of device (I) and (II)

\begin{tabular}{lllllr}
\hline Device & $J_{\text {sc }}\left(\mathrm{mA} \mathrm{cm}^{-2}\right)$ & $V_{\text {oc }}(\mathrm{V})$ & FF $(\%)$ & PCE\% & $R_{\mathrm{s}}\left(\Omega \mathrm{cm}^{-2}\right)$ \\
\hline I & 5.56 & 0.89 & 73 & 3.59 & 11.74 \\
II & 5.69 & 0.9 & 69 & 3.5 & 12.27
\end{tabular}

Therefore, $\mathrm{MoO}_{3} / \mathrm{Ca}$ could be qualified for interconnecting layer in tandem structure cells.

In tandem structure cells, the interconnecting layer not only affects the charge carrier collection, but also influences the optical transmission. ${ }^{20}$ Thus, another important concern that needs to be addressed is the thickness of interlayer. Actually, the interconnecting layer in tandem cells was the holecollecting layer of front cell and electron-collecting layer of rear cell, which was tuned from $7 \mathrm{~nm}$ to $15 \mathrm{~nm}$. Based on our previous study, the active layers thickness of $\mathrm{C}_{70}$ and DBP were set to $40 \mathrm{~nm}$ and $20 \mathrm{~nm}$ in both subcells. ${ }^{15}$ The $J-V$ curves with different interconnecting layer thicknesses were shown in Fig. 3(a), the parameters extracted from $J-V$ curves were summarized in Table 2. The highest PCE obtained from such a tandem structure cell was $3.07 \%$ when the interlayer thickness was $10 \mathrm{~nm}\left(\mathrm{MoO}_{3}(5 \mathrm{~nm}) / \mathrm{Ca}(5 \mathrm{~nm})\right)$, with a $V_{\text {oc }}$ of $1.76 \mathrm{~V}$, a $J_{\mathrm{sc}}$ of $2.46 \mathrm{~mA} \mathrm{~cm}^{-2}$ and a $\mathrm{FF}$ of $71 \%$. It can be found that the tandem structure cells showed a $V_{\text {oc }}$ of $1.76 \mathrm{~V}$, which is approximately equal to the sum of the two subcells. Due to the discontinuous film of $\mathrm{Ca}(2 \mathrm{~nm})$, the $J_{\mathrm{sc}}$ in tandem structure cell with $7 \mathrm{~nm}$ interlayer is only $2 \mathrm{~mA} \mathrm{~cm}{ }^{-2}$. Meanwhile, the $J_{\mathrm{sc}}$ of tandem structure cell is $2.08 \mathrm{~mA} \mathrm{~cm}^{-2}$ when the interlayer thickness is $15 \mathrm{~nm}$, which should be attributed to the energy barrier caused by thick interconnecting layer. ${ }^{21,22}$

In ideal series tandem structure cells, $V_{\mathrm{oc}}$ is sum of the $V_{\mathrm{oc}}$ of each subcells, $J_{\mathrm{sc}}$ is dominated by the smaller one of subcells if the fill factor (FF) is the same in both subcells. ${ }^{23}$ Due to spectral overlap and variation of optical field distribution, $J_{\mathrm{sc}}$ and FF in tandem structure cells differ from the values in subcells. Hence, the $J_{\mathrm{sc}}$ in tandem structure cell is controlled by the subcell with high FF. ${ }^{24}$ Therefore, the thickness of active layers in each subcells were tuned in order to optimize the photovoltaic performance of tandem structure cell. Optimizing the thickness of active layers, the front and rear cells were designed to absorb the long-wave light photons and short-wave light photons, respectively.

For comparison, the $J-V$ curves using different thickness active layers were plotted in Fig. 3(b), the corresponding parameters were summarized in Table 3. The optimal device performance was obtained when the active layers thicknesses of front and rear cells were set to $\mathrm{C}_{70}(20 \mathrm{~nm}) / \mathrm{DBP}(25 \mathrm{~nm})$ and $\mathrm{C}_{70}$ $(40 \mathrm{~nm}) / \mathrm{DBP}(15 \mathrm{~nm})$, with a PCE of $3.81 \%$, a $V_{\mathrm{oc}}$ of $1.77 \mathrm{~V}$, a $J_{\mathrm{sc}}$ of $2.89 \mathrm{~mA} \mathrm{~cm} \mathrm{~cm}^{-2}$ and a $\mathrm{FF}$ of $74 \%$. In order to diminish the absorption overlap of acceptor, $\mathrm{C}_{70}$ was changed to $\mathrm{C}_{60}$ in front subcell. However, the performance of tandem structure cell decreased due to the low $J_{\mathrm{sc}}$, which was ascribed to the weaker absorption of $\mathrm{C}_{60}$ in visible region. The $J-V$ curve was shown in ESI (Fig. SI $3 \dagger$ ).

It has been proved that the dependence of $J_{\mathrm{sc}}$ on incident light intensity reflects the charge carrier recombination behavior in solar cells. ${ }^{25,26}$ To understand the recombination behaviors in tandem structure cells, $J_{\mathrm{sc}}$ as a function of light intensity has been studied in this work, which is determined from the expression: ${ }^{27}$

$$
J_{\mathrm{sc}} \propto I^{\alpha}
$$

Table 2 Summary of tandem structure cells with different interlayer thicknesses. Device structure: ITO/Ca $(1 \mathrm{~nm}) / \mathrm{C}_{70}(40 \mathrm{~nm}) / \mathrm{DBP}(20$ $\mathrm{nm}) / \mathrm{MoO}_{3}(P \mathrm{~nm}) / \mathrm{Ca}(Q \mathrm{~nm}) / \mathrm{C}_{70}(40 \mathrm{~nm}) / \mathrm{DBP}(20 \mathrm{~nm}) / \mathrm{MoO}_{3}(5 \mathrm{~nm}) /$ $\mathrm{Al}$

\begin{tabular}{llllll}
\hline $\begin{array}{l}\mathrm{MoO} \\
\mathrm{nm})\end{array}$ & $\begin{array}{l}\mathrm{Ca}(Q \\
\mathrm{nm})\end{array}$ & $J_{\text {sc }}\left(\mathrm{mA} \mathrm{cm}^{-2}\right)$ & $V_{\text {oc }}(\mathrm{V})$ & $\mathrm{FF} \%$ & PCE\% \\
\hline 5 & 5 & 2.46 & 1.76 & 71 & 3.07 \\
5 & 2 & 2 & 1.77 & 77 & 2.70 \\
10 & 5 & 2.08 & 1.77 & 71 & 2.61
\end{tabular}

(a)

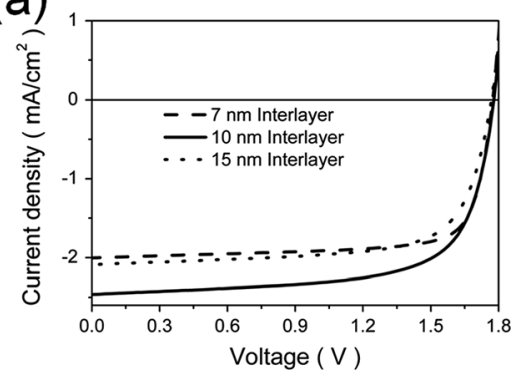

(b)

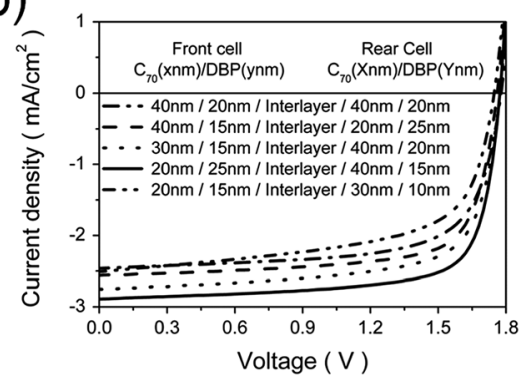

Fig. 3 (a) J-V curves of tandem structure cells with different interlayer thicknesses under simulated AM1.5G solar illumination at $100 \mathrm{~mW}^{-2} \mathrm{~cm}^{-2}$. Device structure: ITO/Ca $(1 \mathrm{~nm}) / \mathrm{C}_{70}(40 \mathrm{~nm}) / \mathrm{DBP}(20 \mathrm{~nm}) / \mathrm{MoO}_{3}(P \mathrm{~nm}) / \mathrm{Ca}(Q \mathrm{~nm}) / \mathrm{C}_{70}(40 \mathrm{~nm}) / \mathrm{DBP}(20 \mathrm{~nm}) / \mathrm{MoO}_{3}(5 \mathrm{~nm}) / \mathrm{Al}$. (b) J-V curves of tandem structure cells with different active layer thicknesses under simulated AM1.5G solar illumination at $100 \mathrm{~mW} \mathrm{~cm}^{-2}$. Device structure: ITO/ $\mathrm{Ca}(1 \mathrm{~nm}) / \mathrm{C}_{70}(x \mathrm{~nm}) / \mathrm{DBP}(y \mathrm{~nm}) / \mathrm{MoO}_{3}(5 \mathrm{~nm}) / \mathrm{Ca}(5 \mathrm{~nm}) / \mathrm{C}_{70}(X \mathrm{~nm}) / \mathrm{DBP}(Y \mathrm{~nm}) / \mathrm{MoO}_{3}(5 \mathrm{~nm}) / \mathrm{Al}$. 
Table 3 Performance optimization of tandem structure cells via varying the active layers thicknesses. ITO/Ca $(1 \mathrm{~nm}) / \mathrm{C}_{70}(x \mathrm{~nm}) / \mathrm{DBP}(y \mathrm{~nm}) /$ $\mathrm{MoO}_{3}(5 \mathrm{~nm}) / \mathrm{Ca}(5 \mathrm{~nm}) / \mathrm{C}_{70}(X \mathrm{~nm}) / \mathrm{DBP}(\mathrm{Y} \mathrm{nm}) / \mathrm{MoO}_{3}(5 \mathrm{~nm}) / \mathrm{Al}$

\begin{tabular}{|c|c|c|c|c|c|c|c|}
\hline $\begin{array}{l}\text { Front cell } \mathrm{C}_{70}(x \\
\mathrm{nm})\end{array}$ & $\begin{array}{l}\text { Front cell DBP } \\
(y \mathrm{~nm})\end{array}$ & $\begin{array}{l}\text { Rear cell } \mathrm{C}_{70}(X \\
\mathrm{nm})\end{array}$ & $\begin{array}{l}\text { Rear cell DBP } \\
(Y \mathrm{~nm})\end{array}$ & $\begin{array}{l}J_{\mathrm{sc}} \\
\left(\mathrm{mA} \mathrm{cm}{ }^{-2}\right)\end{array}$ & $V_{\mathrm{oc}}(\mathrm{V})$ & FF\% & РCE\% \\
\hline 40 & 20 & 40 & 20 & 2.46 & 1.76 & 71 & 3.07 \\
\hline 30 & 15 & 40 & 20 & 2.75 & 1.76 & 70 & 3.38 \\
\hline 20 & 25 & 40 & 15 & 2.89 & 1.77 & 74 & 3.81 \\
\hline 20 & 15 & 30 & 10 & 2.51 & 1.76 & 65 & 2.87 \\
\hline
\end{tabular}
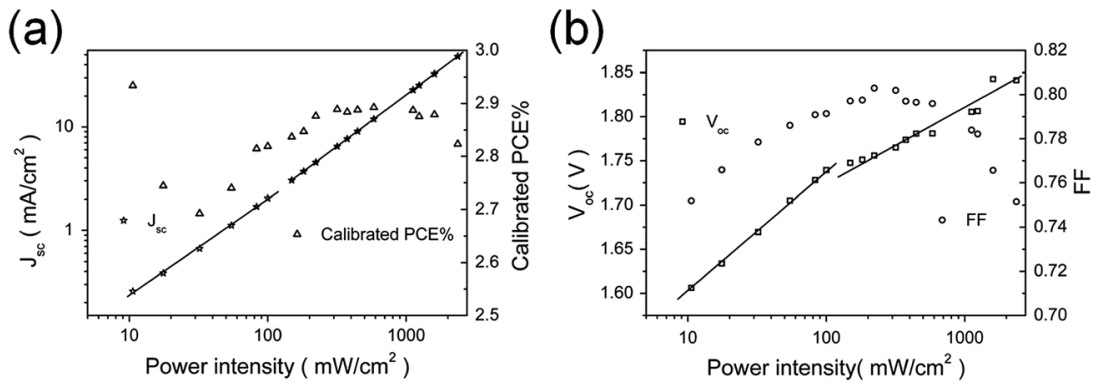

Fig. 4 (a) $J_{\text {sC }}$ (triangles) and calibrated PCE\% (stars) of tandem structure cell as a function of power intensity. The solid lines denote linear fits to the experimental data of $J_{\mathrm{sc}}$. (b) $V_{\mathrm{oc}}$ (squares) and $\mathrm{FF}$ (circles) of tandem structure cell as a function of power intensity. The solid lines denote linear fits to the experimental data of $V_{\text {oc }}$.

where $\alpha$ is close to unity. As shown in Fig. 4(a), the $J_{\text {sc }}$ light intensity were plotted in log-log scale and fitted to power law with eqn (1). The fitting of the data achieved $\alpha=0.96$ (from 10 to $100 \mathrm{~mW} \mathrm{~cm}^{-2}$ ), $\alpha=1$ (from 150 to $2400 \mathrm{~mW} \mathrm{~cm}^{-2}$ ), respectively. Within experimental error, the value of $\alpha$ is identical under low light intensity and high light intensity. The nearly linear dependence of $J_{\mathrm{sc}}$ indicated the weak bimolecular recombination in tandem structure cells, meaning weak recombination at short circuit operating condition. ${ }^{28}$

Under open circuit operating condition, no charge carriers are extracted and the generated charge carriers recombine again in solar cells, which effectively reflects the inside recombination behaviors. Hence, the recombination behaviors can be revealed by the dependence of $V_{\mathrm{oc}}$ upon light intensity. Fig. 4(b) showed $V_{\mathrm{oc}}$ as a function of the logarithmic scale of light intensity. The experimental data were fitted with a linear function with slope $S, S=2.35 \frac{K T}{e}$ (from 10 to $100 \mathrm{~mW} \mathrm{~cm}^{-2}$ ), $S=1.38 \frac{K T}{e}$ (from 150 to $2400 \mathrm{~mW} \mathrm{~cm}^{-2}$ ). It has been proved that $S$ gives $\frac{K T}{e}$ for bimolecular recombination. ${ }^{29}$ However, the experimental data showed a steeper dependence of $V_{\mathrm{oc}}$ on the light intensity. This deviation has been explained by adding trap-assisted Schokley-Read-Hall (SRH) recombination at the donor and acceptor interface in organic solar cells..$^{30,31}$ Due to the competition of SRH and bimolecular recombination, the slope of $V_{\text {oc }}$ with logarithmic scale on light intensity increased with the strength of trap-assisted recombination. The slope under low light intensity is higher than it under high light intensity, which means SRH recombination is more dominant than bimolecular recombination at low light intensity. On the other hand, a low charge carrier mobility in organic semiconductor can boost the formation of space charge giving rise to bimolecular recombination of electrons and holes. Hence, the bimolecular recombination becomes stronger and eventually dominant the inside recombination mechanism of device. ${ }^{32}$ Hence, SRH recombination mechanism is the main loss mechanism in this inverted tandem structure cells. Fig. 4(b) also showed the dependence of FF under light intensity, high FF ( $79 \%$ under $100 \mathrm{~mW} \mathrm{~cm}^{-2}$ ) was observed. Outstanding $\mathrm{FF}$ (over $80 \%$ ) was obtained when the light intensity was about $200 \mathrm{~mW}$ $\mathrm{cm}^{-2}$, which was the highest value reported in organic solar cells.

Photovoltaic cells are working under sunlight in the air. Hence, stability is another key issue for OPVs. In this work, we study the stability of inverted tandem structure cell. As shown in

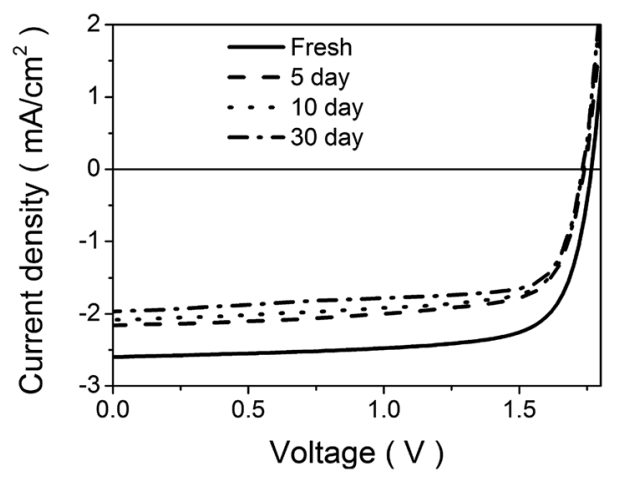

Fig. 5 Stability comparison in air of tandem structure cell. Device structure: ITO/Ca $(1 \mathrm{~nm}) / \mathrm{C}_{60}(20 \mathrm{~nm}) / \mathrm{DBP}(25 \mathrm{~nm}) / \mathrm{MoO}_{3}(5 \mathrm{~nm}) / \mathrm{Ca}(5$ $\mathrm{nm}) / \mathrm{C}_{70}(40 \mathrm{~nm}) / \mathrm{DBP}(15 \mathrm{~nm}) / \mathrm{MoO}_{3}(5 \mathrm{~nm}) / \mathrm{Al}$. 
Fig. 5, the encapsulated cells showed good stability in air. The tandem structure cell showed steep decreasing in five days, the $J_{\mathrm{sc}}$ decreased from $2.89 \mathrm{~mA} \mathrm{~cm}^{-2}$ to $2.16 \mathrm{~mA} \mathrm{~cm}^{-2}$. After that the performance of tandem structure cell became stable. On the other hand, the $V_{\text {oc }}$ showed weak decay in 30 days. This result displays that stability of inverted tandem structure cell is good in DBP and $\mathrm{C}_{70}$ based planar heterojunction cells.

\section{Conclusions}

Inverted tandem structure cells with identical subcells has been studied. This study proved that $\mathrm{MoO}_{3}$ and $\mathrm{Ca}$ is an effective interconnecting layer for vacuum deposited tandem structure cells. On the other hand, charge carrier recombination behaviors are revealed that Schokley-Read-Hall recombination and bimolecular recombination dominates the loss mechanism of cells under low light intensity and high light intensity, respectively. Compared with single junction solar cell, improved PCE, impressive FF and good stability are observed in tandem structure cell. With certain modification, inverted tandem structure could be a potential candidate for improving photovoltaic performance and stability.

\section{Acknowledgements}

This project is sponsored under the Japan Science and Technology Agency (JST) via the Japan Regional Innovation Strategy Program by the Excellence (J-RISE).This research was also supported by Shanxi Provincial Natural Science Foundation of China (Grant No. 201601D021050). This study was also supported by the Qualified Personal Foundation of Taiyuan University of Technology (800101-02030017).

\section{References}

1 J. Jo, J.-R. Pouliot, D. Wynands, S. D. Collins, J. Y. Kim, T. L. Nguyen, H. Y. Woo, Y. Sun, M. Leclerc and A. J. Heeger, Adv. Mater., 2013, 25, 4783.

2 W. Zhao, S. Li, S. Zhang, X. Liu and J. Hou, Adv. Mater., 2017, 29, 1604059.

3 D. Baran, R. S. Ashraf, D. A. Hanifi, M. Abdelsamie, N. Gasparini, J. A. Röhr, S. Holliday, A. Wadsworth, S. Lockett, M. Neophytou, C. J. M. Emmott, J. Nelson, C. J. Brabec, A. Amassion, A. Salleo, T. Kirchartz, J. R. Durrant and I. McCulloch, Nat. Mater., 2017, 16, 363369.

4 M. Li, K. Gao, X. Wan, Q. Zhang, B. Kan, R. Xia, F. Liu, X. Yang, H. Feng, W. Ni, Y. Wang, J. Peng, H. Zhang, Z. Liang, H.-L. Yip, X. Peng, Y. Cao and Y. Chen, Nat. Photonics, 2017, 11, 85-90.

5 F. Zhao, S. Dai, Y. Wu, Q. Zhang, J. Wang, L. Jiang, Q. Ling, Z. Wei, W. Ma, W. You, C. Wang and X. Zhan, Adv. Mater., 2017, 1700144.

6 Q. Zhang, B. Kan, F. Liu, G. Long, X. Wan, X. Chen, Y. Zuo, W. Ni, H. Zhang, M. Li, Z. Hu, F. Huang, Y. Cao, Z. Liang, M. Zhang, T. P. Russell and Y. Chen, Nat. Photonics, 2015, 9, 35-41.
7 Y. Ma, S.-C. Chen, Z. Wang, W. Ma, J. Wang, Z. Yin, C. Tang, D. Cai and Q. Zheng, Nano Energy, 2017, 33, 313-324.

8 M. Riede, C. Uhrich, J. Widmer, R. Timmreck, D. Wynands, G. Schwartz, W.-M. Gnehr, D. Hildebrandt, A. Weiss, J. Hwang, S. Sundarraj, P. Erk, M. Pfeiffer and K. Leo, Adv. Funct. Mater., 2011, 21, 3019.

9 S.-C. Chen, Q. Zheng, Z. Yin, D. Cai and Y. Ma, Org. Electron., 2017, 47, 79-84.

10 X. W. Sun, D. W. Zhao, L. Ke, A. K. K. Kyaw, G. Q. Lo and D. L. Kwong, Appl. Phys. Lett., 2010, 97, 053303.

11 J. You, C.-C. Chen, Z. Hong, K. Yoshimura, K. Ohya, R. Xu, S. Ye, J. Gao, G. Li and Y. Yang, Adv. Mater., 2013, 25, 3973.

12 W. Liu, S. Li, J. Huang, S. Yang, J. Chen, L. Zuo, M. Shi, X. Zhan, C.-Z. Li and H. Chen, Adv. Mater., 2016, 28, 97299734.

13 D. W. Zhao, X. W. Sun, C. Y. Jiang, A. K. K. Kyaw, G. Q. Lo and D. L. Kwong, Appl. Phys. Lett., 2008, 93, 083305.

14 J. Y. Kim, K. Lee, N. E. Coates, D. Moses, T.-Q. Nguyen, M. Dante and A. J. Heeger, Science, 2007, 317, 222.

15 D. Yokoyama, Z. Wang, Y.-J. Pu, K. Kobayashi, J. Kido and Z. Hong, Sol. Energy Mater. Sol. Cells, 2012, 98, 472-475.

16 Z. Wang, D. Yokoyama, X.-F. Wang, Z. Hong, Y. Yang and J. Kido, Energy Environ. Sci., 2013, 6, 249-255.

17 M. C. Scharber, D. Mühlbacher, M. Koppe, P. Denk, C. Waldauf, A. J. Heeger and C. J. Brabec, Adv. Mater., 2006, 18, 789.

18 Y. Sun, C. J. Takacs, S. R. Cowan, J. H. Seo, X. Gong, A. Roy and A. J. Heeger, Adv. Mater., 2011, 23, 2226.

19 Y.-C. Tseng, A. U. Mane, J. W. Elam and S. B. Darling, Sol. Energy Mater. Sol. Cells, 2012, 99, 235.

20 Y. Yuan, J. Huang and G. Li, Green, 2011, 1, 65-80.

21 X. W. Sun, D. W. Zhao, L. Ke, A. K. K. Kyaw, G. Q. Lo and D. L. Kwong, Appl. Phys. Lett., 2010, 97, 053303.

22 S. Sista, M.-H. Park, Z. Hong, Y. Wu, J. Hou, W. L. Kwan, G. Li and Y. Yang, Adv. Mater., 2010, 22, 380-383.

23 A. Hadipour, B. D. Boer and P. W. M. Blom, Org. Electron., 2008, 9, 617-624.

24 S. Sista, Z. Hong, L.-M. Chen and Y. Yang, Energy Environ. Sci., 2011, 4, 1606-1620.

25 R. A. Street and M. Schoendorf, Phys. Rev. B: Condens. Matter Mater. Phys., 2010, 81, 205307.

26 A. K. K. Kyaw, D. H. Wang, V. Gupta, W. L. Leong, L. Ke, G. C. Bazan and A. J. Heeger, ACS Nano, 2013, 7, 4569-4577.

27 J. K. J. V. Duren, X. Yang, J. Loos, C. W. T. Bulle-Lieuwma, A. B. Sieval, J. C. Hummelen and R. A. J. Janssen, Adv. Funct. Mater., 2004, 14, 425-434.

28 I. Riedel, J. Parisi, V. Dyakonov, L. Lutsen, D. Vanderzande and J. C. Hummelen, Adv. Funct. Mater., 2004, 14, 38-44.

29 S. R. Cowan, A. Roy and A. J. Heeger, Phys. Rev. B: Condens. Matter Mater. Phys., 2010, 82, 245207.

30 M. M. Mandoc, W. Veurman, L. J. A. Koster, B. D. Boer and P. W. M. Blom, Adv. Funct. Mater., 2007, 17, 2167-2173.

31 K. S. Nalwa, R. C. Mahadevapuram and S. Chaudhary, Appl. Phys. Lett., 2011, 98, 093306.

32 Z. Wang, Z. Hong, T. Zhuang, G. Chen, H. Sadabe, D. Yokoyama and J. Kido, Appl. Phys. Lett., 2015, 106, 053305. 